\title{
EDUCATIONAL STATUS AND POSTNATAL CARE PRACTICES AMONG DALIT AND JANAJATI WOMEN OF NEPAL
}

\author{
Om Prasad Baral \\ Department of Health Education, TU, Thakur Ram Multiple Campus, Birgunj, Nepal \\ E-mail: ompbaral@gmail.com
}

\begin{abstract}
This paper deals with educational status and postnatal care practices and the association of educational status and postnatal care practices of Dalit and Janajati women of Nepal. The result shows that literacy rate of respondents was 51.4 percent which is lower than the national level women literary rate 57.4 percent of Nepal. PNC (Postnatal Care) visit of Dalits and Janajatis women who visited three times during postnatal period were found to be 36 percent in survey area. PNC visit of respondents is less frequent than the national level PNC checkup (55 percent). Thus, it is recommended that Dalit and Janjati mothers who come for antenatal check up should be provided with adequate information about availability of safe delivery incentive, incentive for postnatal checkup and free health services provided by government of Nepal.
\end{abstract}

\section{Key words}

Association; Dalit and Janajati Women; educational status; postnatal care; postnatal check up

\section{Introduction}

Nepal is multi-cultural, multi-lingual, multiethnic, multi-religiousand Federal Democratic Republic. There are 125 castes/groups and 123 languages spoken as mother tongue. Nepal is preparing to bring marginalized and excluded communities in social inclusion and new nation building process. Dalits and Janajatis are among the most marginalized groups at present in Nepal (CDS/A, 2014).
Approximately 800 women die everyday from preventable causes due to complication arinsing during pregnancy, labour and postpartum and 4 million newborn die during their first month of life with similar number of stillbirths. Ninety nine percent of these deaths occur in developing countries with higher mortality in women from rural areas and among poorer communities. South Asia accounts for almost one third of these global deaths (WHO et al., 2010). Young adolescents 
face a higher risk of complications and death as a result of pregnancy than older women. In South Asia lifetime risk of dying as a resultbof pregnancy or childbirth is 1 in 6o in Nepal it is 1 in 190. The maternal mortality ratio in developing countries in 2013 is 230 per 100000 live births versus 16 per 100000 live births in developed countries(WHO, 2014). The maternal mortality ratio of Nepal is 229 per lakh (DoHS, 2014).

Child birth is not an illness, it has an impact on women's subsequent health ( Mac,1999). Every woman passes through the critical phases of pregnancy, delivery and postnatal period. However, of all the components of maternal and child care delivery, postnatal care and early newborn care are most neglected (FHD, 2007). Nearly 24 percent of maternal deaths occur in the antepartum and $16 \%$ occur in the intrapartum period, the majority, 6o percent of maternal deaths, occur during the immediate postpartum period (MoH et al., 2012).

The postnatal period defined as one hour following the delivery of the placenta through the first six weeks of an infant's life is particularly important. During this period, mothers may develop serious life threatening complications after delivery (MoHP et al., 2012). Various studies show that the kind of complications following childbirth such as chronic pain, impaired mobility, damage to the reproductive system, genital prolapsed and infertility are very common in developing countries (Dhakal et al., 2007).

The postnatal period is the ideal time to deliver interventions to improve the health and survival of both the newborn and the mother (Matijaservich et al., 2009). Postnatal care helps to identify complications, promote healthy behaviors, ensures the establishment of successful infants feeding, links the mother to family planning services and the baby to child health care as well as fostering the development of good maternal infant relationship. According to WHO guidelines on postpartum care, theaim of care in postpartum period should be to support mother and her family costellation, prevention and early diagnosis and treatmentof complications of mothers and infant as well as counseling on baby care breastfeeding, immunization and family planning. Moreover, it is stressed that given the limited resources, the contact with the health care system at least during the first twenty four hours and before the end of the first week is the most effective strategy . However, postnatal care has long been neglected or fragmented and data for postnatal care, are either unavailable or show low level coverage in a large number of countries (WHO, 2006). The national safe motherhood program recommends that women delivering in ahealth facility should remain for observation for the first 24 hours period, and those deliver at home need close observation as well, preferably by a skilled birth attendant who can recognize signs of problems, manage, and refer immediately when needed. In total, three postnatal visits is recommended for all omen, whether delivered at home, or in a facility; first visit within 72 hours, $2^{\text {nd }}$ visit with 4-7 days and $3^{\text {rd }}$ visit within 42 days ( DoHS, 2009).

Evidence has shown that large proportion of deaths occur during the postpartum period. Postnatal check up provide an ideal opportunity in educating new mother on how to care for herself and her new born during this period ought to prevent these deaths to large extent. Governmentof Nepal has been trying to increase the utization of maternal health services including PNC services through expanding birthing center and training skilled birth attendance. Similarly, the commitment reiterated in many policy and planning douccuments including national health policy, Nepal health sector program implementation plan II, safe motherhood and neonatal health long term plan and safe motherhood policy.

This report is based on the study carried out (Baral, 2015) in Kaski and Parsa districts of Nepal. 
Table 1: Educational Status of Respondents

\begin{tabular}{|l|l|c|c|c|c|c|c|c|}
\hline \multirow{2}{*}{$\begin{array}{c}\text { Caste/ } \\
\text { Ethinic } \\
\text { group }\end{array}$} & $\begin{array}{c}\text { Number } \\
\text { and } \\
\text { Percent }\end{array}$ & $\begin{array}{c}\text { Illiter- } \\
\text { ate }\end{array}$ & $\begin{array}{c}\text { Literate } \\
\text { but no } \\
\text { school- } \\
\text { ing }\end{array}$ & $\begin{array}{c}\text { Primary } \\
\text { educa- } \\
\text { tion }\end{array}$ & $\begin{array}{c}\text { Lower } \\
\text { second- } \\
\text { ary edu- } \\
\text { cation }\end{array}$ & $\begin{array}{c}\text { Second- } \\
\text { ary edu- } \\
\text { cation }\end{array}$ & $\begin{array}{c}\text { Higher } \\
\text { educa- } \\
\text { tion }\end{array}$ & Total \\
\hline Dalits & Number & 162 & 37 & 27 & 23 & 36 & 15 & 300 \\
\cline { 2 - 10 } & Percent & 54.0 & 12.3 & 9.0 & 7.7 & 12.0 & 5.0 & 100.0 \\
\hline Janajati & Number & 81 & 40 & 10 & 28 & 25 & 16 & 200 \\
\cline { 2 - 10 } & Percent & 40.5 & 20.0 & 5.0 & 14.0 & 12.5 & 8.0 & 100.0 \\
\hline Total & Number & 243 & 77 & 37 & 51 & 61 & 31 & 500 \\
\cline { 2 - 9 } & Percent & 48.6 & 15.4 & 7.4 & 10.2 & 12.2 & 6.2 & 100.0 \\
\hline
\end{tabular}

\section{Methods and Materials}

This study is based upon descriptive survey design of research. Quantitative data were collected to accomplish the study with the help of questionnaire. The study was based on primary sources of data. Cluster sampling technique was used in the selection of Dalit and Janajati women having at least one child from the study area- Parsa and Kaski district of Nepal. The sample consisted of 500 women (30o Dalit and 200 Janajati). Bishrampur VDC145 Dalit and from Bageswari Titrauna VDC -95 Janajati women were selected randomly. In the same way, 155 - Dalit and 105 - Janajati women were selected from Pumdi Bhumdi VDC of Kaski district. I developed and used a structured questionnaire on the basis of literature related to educational status and postnatal care practices in order to collect required data for the completion of this research work. After collecting the necessary information they were analysed quantitatively. Frequency distribution, cross tables and nonparametric Chi-square test were calculated to the association between independent and dependent variables to support the research objectives. The field survey was conducted during 2014.

\section{Results and discussion}

The results have been presented and discussed under educational status, frequency of postnatal check-up and association between educational status and frequency of postnatal check-up.

\section{Educational status of Dalit and Janajati respondents}

It is crucial and essential to find out the educational status of the respondents so as to conduct the research. To a greater extent, education of the respondents affects safe motherhood practices in the target community.

Table 1 reveals that 59.5 percent of Janajati and 46 percent of Dalit were literate in comparison to average national literacy rate of 65.9 percent (CDS/A, 2014). Among Dalit literate respondents, 12.3 percent were literate but no schooling, 9 percent had primary, 7.7 percent had lower secondary, 12 percent had secondary and 5 percent had higher education. On the other hand, among Janajati respondents, 20 percent were literate but no schooling, 5 percent had primary, 14 percent lower secondary, 12.5 percent secondary and 8 percent higher education.

It is clear that educational status of Dalit and Janajatis is low in comparison to national level literacy rate.

\section{Frequency of postnatal checkup}

All mothers and family member must know 
Table 2: Frequency of postnatal check up

\begin{tabular}{|c|c|c|c|c|c|c|}
\hline \multirow{2}{*}{$\begin{array}{c}\text { Caste/ } \\
\text { Ethinic } \\
\text { group }\end{array}$} & \multirow[b]{2}{*}{ Number and Percent } & \multicolumn{3}{|c|}{$\begin{array}{c}\text { Frequency of postnatal } \\
\text { check up }\end{array}$} & \multirow[b]{2}{*}{$\begin{array}{c}\text { No } \\
\text { check } \\
\text { up }\end{array}$} & \multirow[b]{2}{*}{ Total } \\
\hline & & ITime & $\stackrel{2}{\text { Times }}$ & Times & & \\
\hline \multirow{2}{*}{ Dalits } & Number & 94 & 13 & 1 & 192 & 300 \\
\hline & Percent & 31.3 & 4.3 & 0.3 & 64.0 & 100.0 \\
\hline \multirow{2}{*}{ Janajati } & Number & 76 & 0 & 0 & 124 & 200 \\
\hline & Percent & 38.0 & 0.0 & 0.0 & 62.0 & 100.0 \\
\hline \multirow{2}{*}{ Total } & Number & 170 & 13 & 1 & 316 & 500 \\
\hline & Percent & 34.0 & 2.6 & 0.2 & 63.2 & 100.0 \\
\hline
\end{tabular}

about postnatal check up during postnatal period. After delivery both mother and infant need to be checked by health professionals to maintain their health status. Postnatal mother should receive at least three postnatal checkups; the first being within 24 hours of delivery, second visit on the third day following delivery and the third being on the seventh day after delivery (DoHS, 2010).
Table 2 presents that among total respondents, 34 percent had checked one time, 2.6 percent checked two times, only 0.2 percent checked three times whereas a higher 63.2 percent had not checked postnatal check up during postnatal period.

Post-natal checkup is less frequently conducted practice in the present context of Nepal. It is concluded that the respondents'

Table 3: Association between education status and frequency of postnatal check up

\begin{tabular}{|c|c|c|c|c|}
\hline \multirow[b]{2}{*}{ Respondents Educational Status. } & \multicolumn{3}{|c|}{ Frequency of Postnatal Check Up } & \multirow[b]{2}{*}{$\begin{array}{c}\text { No check } \\
\text { up }\end{array}$} \\
\hline & one time & Two times & $\begin{array}{l}\text { Three } \\
\text { times }\end{array}$ & \\
\hline Illiterate & $\begin{array}{l}36 \\
14.8 \%\end{array}$ & $\begin{array}{l}1 \\
0.4 \% \\
\end{array}$ & $\begin{array}{l}1 \\
0.4 \% \\
\end{array}$ & $\begin{array}{l}205 \\
84.4 \%\end{array}$ \\
\hline Literate & $\begin{array}{l}14 \\
18.2 \%\end{array}$ & $\begin{array}{l}3 \\
3.9 \%\end{array}$ & $\begin{array}{ll}\mathrm{O} \\
\mathrm{o} \% \\
\end{array}$ & $\begin{array}{l}60 \\
77 \cdot 9 \%\end{array}$ \\
\hline Primary education & $\begin{array}{l}14 \\
37.8 \%\end{array}$ & $2.4 \%$ & \begin{tabular}{|l|}
$\mathrm{O}$ \\
$\mathrm{O} \%$ \\
\end{tabular} & $\begin{array}{l}21 \\
56.8 \%\end{array}$ \\
\hline Lower secondary education & $\begin{array}{l}31 \\
60.8 \%\end{array}$ & 2 & \begin{tabular}{|l|}
$\mathrm{O}$ \\
$\mathrm{O} \%$ \\
\end{tabular} & $\begin{array}{l}18 \\
35 \cdot 3 \%\end{array}$ \\
\hline Secondary education & $\begin{array}{l}48 \\
78.7 \%\end{array}$ & $6.6 \%$ & $\begin{array}{l}\mathrm{O} \\
\mathrm{O} \%\end{array}$ & 9 \\
\hline Higher education & $\begin{array}{l}27 \\
87.1 \%\end{array}$ & $\begin{array}{l}1 \\
3.2 \%\end{array}$ & \begin{tabular}{|l|}
$\mathrm{o}$ \\
$\mathrm{o} \%$ \\
\end{tabular} & $\begin{array}{l}3 \\
9.7 \%\end{array}$ \\
\hline Total & $\begin{array}{l}170 \\
34 \%\end{array}$ & $\begin{array}{l}13 \\
2.6 \%\end{array}$ & 1 & $\begin{array}{l}316 \\
63.2 \%\end{array}$ \\
\hline
\end{tabular}

$\chi^{2}=78.73, \mathbf{d f}=15, p=.001$ 
postnatal check up is less frequent and irregular than the national level check up status. In comparing Dalit and Janajati respondents, Janajati had their postnatal check up conducted more frequently than that of Dalits. The result shows that most of Dalit respondent did not obtain postnatal visit because of low importance for postnatal check up and unawareness of PNC visit.

Table 3 shows that among the illiterate respondents, 14.8 percent reported to have gone for check up only once, 0.4 percent two times and the same 0.4 percent three times whereas the highest 84.4 percent attended no postnatal check up. Among the literate respondents, 18.2 percent reported to have gone for check up only one, 3.9 percent two times but the highest 77.9 percent have not attended any checkup. Among the respondents having primary education, 37.8 percent reported to have gone for check up only once, 5.4 percent two times and 56.8 percent attended no checkup. Among the respondents having secondary education, 58.7 percent reported to have gone for check up only one, 6.6 percent two times, remaining (14.8 percent) attended no checkups. Among the respondents having higher secondary education, 87.1 percent reported to have gone for check up only one, 3.2 two times but 9.7 percent attended no checkup during postnatal period.

The significance of association between educational status of Dalit and Janajati women and frequency of postnatal check up was tested statistically by applying chisquare test. The computed chi-square value was found to be $\chi^{2}=78.73$ which is not less than the table value 24.99 , so the association between educational status and frequency of postnatal check up is significant at the 0.05 level of significance. Thus, the hypothesis that there exists significant association between educational status and frequency of postnatal check up is accepted. It may be said that higher educational status of the respondents had more frequent postnatal check up visit they attended during postnatal period than that of uneducated women.

Table 4: Association between educational status of respondents' spouses and frequency of postnatal check up

\begin{tabular}{|c|c|c|c|c|}
\hline \multirow[t]{2}{*}{ Spouses Educational Status } & \multicolumn{4}{|c|}{ Frequency of Postnatal Checkup } \\
\hline & one time & Two times & $\begin{array}{l}\text { Three } \\
\text { times }\end{array}$ & $\begin{array}{c}\text { No check } \\
\text { up }\end{array}$ \\
\hline Illiterate & $\begin{array}{c}32 \\
16.2 \% \\
\end{array}$ & $\begin{array}{c}3 \\
1.5 \% \\
\end{array}$ & $\begin{array}{c}1 \\
0.5 \% \\
\end{array}$ & $\begin{array}{c}161 \\
81.7 \% \\
\end{array}$ \\
\hline Literate & $\begin{array}{c}9 \\
18.4 \% \\
\end{array}$ & $\begin{array}{c}1 \\
2 \% \\
\end{array}$ & $\begin{array}{c}\mathrm{o} \\
\mathrm{o} \% \\
\end{array}$ & $\begin{array}{c}39 \\
79.6 \% \\
\end{array}$ \\
\hline Primary education & $\begin{array}{c}29 \\
28.7 \% \\
\end{array}$ & $\begin{array}{c}2 \\
2 \% \\
\end{array}$ & $\begin{array}{c}\mathrm{O} \\
\mathrm{O} \% \\
\end{array}$ & $\begin{array}{c}70 \\
69.3 \% \\
\end{array}$ \\
\hline Lower secondary education & $\begin{array}{c}30 \\
56.6 \% \\
\end{array}$ & $\begin{array}{c}2 \\
3.8 \% \\
\end{array}$ & $\begin{array}{c}\mathrm{O} \\
\mathrm{O} \% \\
\end{array}$ & $\begin{array}{c}21 \\
39.6 \% \\
\end{array}$ \\
\hline Secondary education & $\begin{array}{c}41 \\
67.2 . \%\end{array}$ & $\begin{array}{c}4 \\
6.6 \% \\
\end{array}$ & $\begin{array}{c}\mathrm{o} \\
\mathrm{O} \%\end{array}$ & $\begin{array}{c}16 \\
26.2 \% \\
\end{array}$ \\
\hline Higher education & $\begin{array}{c}29 \\
74.4 \%\end{array}$ & $\begin{array}{c}1 \\
2.6 \% \\
\end{array}$ & $\begin{array}{c}\mathrm{O} \\
\mathrm{O} \% \\
\end{array}$ & $\begin{array}{c}9 \\
23.1 \%\end{array}$ \\
\hline Total & $\begin{array}{l}170 \\
34 \%\end{array}$ & $\begin{array}{c}13 \\
2.6 \%\end{array}$ & $\begin{array}{c}1 \\
0.2 \%\end{array}$ & $\begin{array}{c}316 \\
63.2 \%\end{array}$ \\
\hline
\end{tabular}

$\chi^{2}=76.81, \mathbf{d f}=15, \mathrm{p}=.000$ 
Table 4 shows that among the respondents of illiterate spouses, 16.2 percent were found to have gone for check up only once, 1.5 percent twice and the same 1.5 percent thrice whereas a higher 81.7 percent not to have attended any postnatal check up. Among the respondents whose spouses had primary education, 28.7 percent were found to have gone for check up only once, 2 percent twice, o percent thrice but 69.3 percent not attend any check up. Among the respondents whose spouses had secondary education, 67.2 percent were found to have gone for check up only one, 6.6 percent twice, and remaining (26.2 percent) not to have attended any checkup. Among the respondents whose husbands had higher secondary education, 74.4 percent were found to have gone for check up only one, 2.6 percent twice and 9.7 percent not to have attended any checkup during postnatal period.

The significance of association between educational status of respondents' spouses and frequency of postnatal checkup was tested statistically by applying Chi-square test. The computed Chi-square value was found to be $\chi^{2}=76.81$ which is not less than the table value 24.99 , so the association between educational status of respondents' spouses and frequency of postnatal is significant at the 0.05 level of significance. Thus, the hypothesis that there exists significant association between educational status respondents' spouses and frequency of postnatal is accepted. It may be said that the adoption of postnatal check up is positively associated with educational status of spouses i.e. educated respondents' spouses are aware of more frequency of postnatal check up than that of uneducated respondents' spouses.

\section{Conclusion}

The educational status of women of Dalit and Janajati was not satisfactory and lower than national level educational status. Practice of postnatal check up was very poor in the study area and more declining than the national level data. This practice was found better among educated respondents as compared to illiterates.

\section{References}

Baral, O. P. ( 2015). A study of educational status and postnatal care practices among Dalit and Janajati women of Nepal. Ph. D. dissertation, School of Education, Jaipur National University, Jaipur, India.

CDS/A, T.U. (2014). Nepal social inclusion survey 2012. Kathmandu: Author.

DoHS (2009). Annual Report 2008/2009. Government of Nepal.Kathmandu : Author.

DoHS (2010). Annual Report 2009/2010. Government of Nepal.Kathmandu : Author.

DoHS (2014). Annual Report 2013/2014.Government of Nepal.Kathmandu : Author.

DoHS (2015). Annual Report2014/2015 Government of Nepal Kathmandu: Author.

Dhakal, S., Chapman,G.N., Simkhada P.P.,Van, E.R., Stephen, J. \& Raja, A.E. (2007). Utilization of Postnatal care among rural women in Nepal. BMC Pregnancy and Child Birth 7 (1): 19.

FHD (2007). National medical standard for reproductive health . Kathmandu: MoHP.

Mac, C. (1999). What does postnatal care do for women's health ? Lancet 353(9150):343-4.

MoHP (2012). Amma surakshya program guidelines, second revision. Kathmandu: MoHP.

MoHP, NEW ERA, JCF International Inc. (2012). Nepal demographic health survey 2011 Kathmandu: Authors.

WHO (2006). Pregnancy, childbirth, postpartum and newborn care: A guide for essential practice. Geneva : World Health Organization .

WHO, UNICEF, UNFPA and The World Bank (2010). Trends in maternal mortality 1990 to 2010. Geneva: WHO

WHO (2014). Maternal mortality fact sheet. Bangkok : World Health Organization Country Office. 